\title{
Nad dvěma knihami Jany Juhásové
}

\author{
Ivo Pospíšil (Brno)
}

Jana Juhásová: Od symbolu k latencii. Spirituálna téma a žáner v súčasnej slovenskej poéziil. Ružomberok: Verbum, 2016. 152 s. ISBN 978-80-561-0364-7.

Jana Juhásová: Litanická forma od avantgardy po súčasnost'. Ružomberok: Verbum, 2018. 223 s. ISBN 978-80-561-0562-7.

Slovakistka z Katolické univerzity v Ružomberku přispěla $\mathrm{k}$ bádání o poezii obecně a slovenské zvláště výrazně a originálně. Dobře tu navázala na výzkum Jána Zambora, Zoltána Rédeye a dalších. Zkoumání transgrese od symbolu jako nejvýznamnějšího tropu moderní poezie ke skrytosti a utajenosti, můžeme volně dodat zamlklosti poezie, ${ }^{1}$ je v první knize probírána na materiálu slovenské duchovní poezie moderní doby a rámcována genologickými kategoriemi. Přelom tisíciletí je svědkem trvalejšího návratu $\mathrm{k}$ duchovnosti obecně a v literatuře včetně poezie zvláště. Autorka to přesně zachytila, stejně jako renesanci biblické intertextuality. Již zde se také rýsuje bádání o spojitosti moderny, avantgardy a katolické lyriky. Ukazuje, kterak vývoj slovenské poezie souvisí s posuny v evropské a světové poezii na materiálu poezie etablující se skupiny básníků jako jsou např. V. Klimáček, R. Bielik, I. Kolenič aj. a př́mo spirituálními poety typu R. Jurolka, E. J. Grocha, J. Gavury nebo P. Milčáka. Po pravdě řečeno, monografická celistvost se v toto knize projevuje spíše v její první polovině, kde je interpretována poezie Milana Rúfuse a Erika Jakuba Grocha jako představitelů dvou zcela odlehlých generací, básníků sice blízkých, ale nikoli identických: oba postupují k duchovnímu tématu, na němž autorka ukazuje přechod od symbolu k latenci, akcentaci tajemství, která mají být toliko poodhalena. U Rúfuse si všimla jeho eseje o návratu symbolu do slovenské poezie z roku 1969. Sleduje také povlov-

1 Viz brněnský česko-slovenský svazek Česká a slovenská poezie: Slovo a mlčeni. Eds. Ivo Pospíšil - Anna Zelenková. Brno: Česká asociace slavistů, 2015. né působení duchovní lyriky v podání Czesława Miłosze a Zbigniewa Herberta, poměrně skromně jsou tu zastoupeny aluze na českou poezii tohoto typu. byt její vliv na slovenské básnictví tohoto směru je mimo veškerou pochybnost. V druhé polovině knihy její celistvost povoluje a rozostřuje se do případových mikrostudií, např. o Rudolfu Jurolkovi nebo o žánru modlitby s návazností na litaničnost poezie. Zde si autorka otvírá dveře k dalšímu bádání, jež má následovat. Z první části monografie př́liš nerozumím významu takto použitého termínu „pulzace“, jenž znám od sebe a později od Petra Zajace, ale pokaždé v jiném, i když blízkém významu. Autorka ukázala slovenskou duchovní lyriku s jejím sklonem $\mathrm{k}$ symboličnosti a latenci jako podstatnou součást slovenského literárního vývoje, dokonce bych řekl jako její jádro. Nemusí to být zcela pravda: někde se mi zdá, že fascinace interpretací vede autorku k oslabování teoretické konstrukce (jak se někdy říká: všechno lze interpretovat), nebot́ interpretovat může jen ten, kdo ví, tedy zná faktografii, ale také širší souvislosti. Tuto rozhleděnost Juhásová prokázala na několika místech i tím, že sebrala obrovské množství primární, pramenné i sekundární literatury, i když příliš jednosměrné a jednostrunné - alespoň podle mého názoru. Možná by knize slušelo i silnější scelení, jak jsme výše naznačili, tedy změkčení zjevných hiátů mezi jednotlivými kapitolami, vlastně původně autonomními studiemi, ale ani to není pro mě podstatné. Sonda, jakou představuje tato práce, je pro poznání slovenské poezie období zlomu důležitá. To, co dále hodnotím kladně, je ideová 
nepředpojatost, otevřenost, byt ne úplná - spíše bych to nazval pootevřeností - to se bohužel projevilo i v absenci některých textů, které se jí možná nedostaly do rukou nebo je prostě nepovažovala za důležité - důvody mohou být i jiné.

V druhé knize již přistoupila ke zkoumání určitého typu poezie, řekl bych žánrové formy, která s autorčiným zaměřením úzce souvisí - litanie. ${ }^{2}$ Litanii nazývá autorka útvarem mezi žánrem a tendencí, ale tak lze v podstatě nazývat každý žánr, snad s výjimkou románu, který jako by obepínal vše. V první kapitole se Juhásová zabývá genezí litanické poezie a opírá se v tom o řadu děl sekundární literatury. Žánrová matrice jde dál, daleko za křestanskou tradici do starého Sumeru a Egypta, jak o tom píse polský genolog Witold Sadowski v knize Litania i poezja (2011). Materiál, k němuž se potom autorka povlovně sune, je rozsáhlý: od francouzské dekadence v podání Charlese Baudelaira (litanie k Satanovi) k Bretonovi, k Halasovým Starým ženám (1935) a Ginsbergovu Kvileni; nezapomíná ani na Nezvalovy surrealistické sbírky, zejména Žena v množném č́sle (Odkazuje k Winczerově studii o Nezvalově sbírce a uvedené Halasem). Kvalitní je zejména kapitola o litaničnosti u slovenských nadrealistů a o katolické moderně: namátkou Rudolf Fabry, Štefan Žáry, Vladimír Reisel; a kniha se pomalu přesouvá z roviny genologie dál a překlápí se do teorie verše. Snad klíčovou partií je vylíčení vztahu Pala Olivy k avantgardě (Oblaky, 1939). Vývoj litanie vede autorku k Mihálikovi inspirovanému Claudelem a k pokusu o typologii litanie jako proměnlivého útvaru, jenž se stává nástrojem individuálního básnického díla, zejména u skupiny katolických básníků (např. Janko Silan, Rudolf Dilong). Pozoruhodné jsou autorčiny úvahy

2 Viz také tematicky blízkou knihu naší doktorandky a doktorky Evy Niklesové Dialogy zoufalcui: poetika a struktury. Brno: Masarykova univerzita, 2016. o podobě litanické poezie v druhé polovině 20. století; ukazuje na spojitosti s literárními směry, včetně socialistického realismu. Jak tomu bývá i u jiných žánrů, litanie nebo litanické útvary mají různé funkce a slouží různým účelům a názorům, včetně nesouhlasu se společenským systémem. Autorka názorně prezentuje litanickou poezii jako dynamickou, proměnlivou, „rozpohybovanou“, vyjadřující také deziluze v podobě dystopie. Tato dynamizace má však i svůj konstantní úkol v návratech $\mathrm{k}$ původním žánrovým, modelům, např́klad k mariánskému pretextu.

Autorka uchopila litanii jako útvar, který se svou flexibilitou podílí na vývoji literatury otevřeně, ale i jako spodní proud poezie, spojující často její protilehlé polohy tvarové i ideové. Vidím tak litanii jako relativně univerzální výraz lidské situace ve světě, jako výraz antropologické dominanty a obraz člověka v chaosu vesmíru. V této knize se autorce o něco lépe než v předchozí podařilo vytvořit opravdu celistvou entitu, komplexní pohled na podstatnou část vývoje slovenské, ale i evropské poezie. Je zde doceněna česká poezie $\mathrm{v}$ jejích různých podobách, jež dokazují scelující roli litanie (surrealismus, katolická poezie). Litanii lze tedy chápat i jako určité prizma, jímž může být nahlížena poezie jako taková a její často skryté nebo poloskryté polohy. To tuto knihu spojuje s výkladem latence, který najdeme v první knize. Zůstává ovšem ne zcela zodpovězená otázka, proč se tento typ poezie oživuje právě nyní, včetně eschatologické dimenze - to je však téma spíše pro sociologa a sociálního psychologa, i když autorka se ani těmto sférám nevyhýbá. U obou publikací nutno ocenit také celkovou vědeckou akribii, jmenné rejstř́íky, ediční poznámku a seznamy literatury. Snad se v blízké budoucnosti dočkáme od autorky nějakého dalšího pokračování.

\section{prof. PhDr. Ivo Pospišil, DrSc.}

Ústav slavistiky

Filozofická fakulta, Masarykova univerzita

Arna Nováka 1, 60200 Brno, Česká republika

ivo.pospisil@phil.muni.cz 